\title{
EKSPLORASI VARIASI SUMBERDAYA PARIWISATA LOKAL UNTUK BERTAHAN DARI SERANGAN PANDEMI COVID-19
}

\author{
1Agung Prabowo, ${ }^{2}$ Medi Trilaksono Dwi Abadi, 3Yenni Sri Utami \\ 1,2,3Universitas Pembangunan Nasional "Veteran" Yogyakarta \\ 1agung.prabowo@upnyk.ac.id, 2meditrilaksono@upnyk.ac.id, \\ 3yenni.sriutami@upnyk.ac.id
}

\begin{abstract}
Information and communication technology has consistently changed the culture and way of seeing people in traveling. Tourism activities that were previously only a complementary priority are now turning into a top priority for the community. The high interest in traveling stimulates the creativity of various groups of people to explore the potential of their area to become a tourist destination. Geographical, culinary, handicraft and cultural potentials are growing in various regions. Pasar Setu Minggu (Semi) Kaki Langit is one of the tourist destinations developed by the Mangunan community by exploring regional potential and traditional culinary wealth. The development is quite good and able to lift the people's economy. However, after Covid-19 occurred, for four months there were no visits at all. Market facilities that have no activity have become a little neglected. However, after signs of community tourism activity improved, residents were excited to improve tourist facilities based on Covid-19. The change in the concept of tourism based on Covid-19 certainly needs to be communicated to consumers. Information and communication technology and delivering interesting content are expected to be able to accelerate the recovery of Kaki Langit tourism. This community service aims to help restore Kaki Langit tourist destinations through packaging of local products.
\end{abstract}

Keywords: Kaki Langit, Community Based Tourism, Promotion, Packaging.

\begin{abstract}
Abstrak
Kegairahan berwisata masyarakat mulai nampak seiring dengan majunya teknologi komunikasi. Meningkatnya minat berwisata ini direspon oleh kelompok masyarakat pengelola pariwisata dengan meningkatkan pelayanan dan kreativitas objek wisata. Potensi-potensi geografis, kuliner, kerajinan dan budaya menjadi andalan untuk menarik pengunjung. Perkembangan ini menimbulkan dampak ekonomi yang signifikan. Meskipun pandemi Covid-19 telah menghentikan pendapatan pengelola objek wisata, masyarakat menggali potensi alam yang bisa dimanfaatkan sebagai support product wisata. Di Desa Wisata Pasar Setu Minggu (Semi) Kaki Langit, masyarakatnya mengembangkan produk jamu dan pengolahan kayu untuk memperkuat
\end{abstract}


brand Kaki Langit. Kegiatan ini dilakukan selain untuk tetap bertahan dari serangan pandemi Covid-19, juga untuk mempertahankan brand Kaki Langit sebagai tujuan wisata kuliner. Dalam pengabdian ini dilakukan pendampingan mem-branding produk tersebut serta mendisainkan kemasan yang artistik dan ramah lingkungan

Keywords: Kaki Langit, Community Based Tourism, Promosi, Pengemasan.

\section{PENDAHULUAN}

Desa wisata kaki langit sebagai desa mitra dalam program pengabdian masyarakat yang diajukan, adalah desa wisata yang terletak di Desa Mangunan, kecamatan Dlingo, kabupaten Bantul, Daerah Istimewa Yogyakarta. Desa Kaki Langit yang berada di padukuhan Mangunan secara geografis terletak di Perbukitan sebelah barat Kecamatan Dlingo yang berbatasan dengan Desa Muntuk, Dlingo, Bantul. Potensi yang dimiliki desa ini adalah kondisi alam di pernukitan yang masih asri dan adat istiadat serta kebudayaannya yang masih dijunjung tinggi. Desa ini kaya wisata alam dengan aneka flora dan fauna sehingga bisa menjadi daya tarik bagi wisatawan. Wisata alam Desa Mangunan, antara lain: kebun buah, hutan pinus, watu lawang, watu goyang, watu mabur, seribu batu, jurang tembelan, mojo panguk, telogo giri dan goa gajah. Pemandangan alam yang masih asri juga menjadi pesona tersendiri bagi para wisatawan.
Pengembangan Desa Wisata Mangunan Imogiri Bantul adalah sebagai sarana untuk mewadahi masyarakat yang cinta terhadap desanya untuk bekerjasama melakukan kegiatan pariwisata. Selain sebagai pengikat melalui nilai kearifan lokal, kegiatan ini juga bisa meningkatkan kesejahteraan masyarakat. Model pengembangan pariwisata semacam ini adalah konsep community based tourism (CBT). Konsep pariwisata berdasar CBT meningkatkan partisipasi masyarakat. Di Desa Wisata Kakilangit Mangunan pengelolanya adalah masyarakat pedukuhan Mangunan. Masyarakat membentuk Pengelola Desa Wisata yang di dalamnya terdapat berbagai unsur yang berperan. Pada tahun 2016 Desa Wisata Mangunan berhasil mendapat penghargaan terbaik ke tiga untuk kategori desa wisata berbasis CBT di tingkat propinsi.

Di antara beberapa potensi yang dimiliki oleh desa wisata Mangunan adalah pembuatan jamu tradisional. Bahan mentah jamu tradisional tidak sulit diperoleh di 
lingkungan Mangunan. Sebelumnya potensi ini kurang memperoleh perhatian. Namun seiring dengan berhentinya aktivitas wisata di Pasar Semi, potensi jamu tradisional ini mulai digarap masyarakat. Hasilnya ternyata cukup mampu menutup kebutuhan sehari-hari.

Selain jamu, kerajinan kayu juga merupakan usaha andalan. Melihat potensinya, kerajinan ini dapat dikembangkan menjadi sentra kerajinan unggulan. Produk dari kerajinan kayu saat ini adalah atap limasan, gantungan kunci, tempat lilin, gilingan kue. Pemasarannya masih terbatas, sehingga memiliki kemungkinan untuk dipasarkan lebih luas melalui media internet. Untuk itu diperlukan media promosi pemasaran yang sesuai, seperti web maupun media sosial yang lain.

Potensi tanaman lokal Desa Wisata Kaki Langit mendukung dikembangkannya aneka usaha kuliner tradisional seperti, Thiwul, Gathot, dan Ubi. Wisatawan dapat menjumpai aneka jajanan tradisional tersebut di Pasar Semi Kaki Langit. Namun yang disayangkan pasar kuliner tersebut hanya berlangsung pada hari Sabtu dan ahad saja. Padahal di hari biasa jumlah wisatawan di desa Mangunan cukup banyak. Akibatnya para pedagang kuliner tradisional tersebut tidak produktif dihari lain.

Sebagai desa wisata berbasis CBT desa Kaki Langit sudah memperoleh beberapa kali penghargaan di tingkat propinsi. Potensi untuk bisa berprestasi pada tingkat nasional sebetulnya sangat memungkinkan mengingat ketersediaan sarana dan prasarana yang terus ditingkatkan, seperti penataan spot-spot wisata, juga keberadan homestay yang semakin representatif bagi wisatawan.

Setelah dianalisis, terdapat beberapa potensi kekuatan, kelemahan, ancaman serta potensi Kaki Langit seperti diuraikan sebagai berikut:

Strength

1. Memiliki potensi wisata alam dan budaya yang bagus

2. Memiliki sentra kerajinan kayu yang sudah berjalan

3. Memiliki sentra wisata kuliner tradisional yang sudah berjalan.

4. Memiliki homestay yang nyaman

5. Memiliki potensi SDM Karangtaruna Weakness

1. Potensi wisata yang ada masih banyak yang belum tergarap dengan baik.

2. Kemasan produk kerajinan dan kuliner masih tradisional dan kurang menjual 
3. Belum adanya keseragaman dan kemampuan sumber daya manusia yang tergabung dalam komunitas Desa Wisata Kaki langit

4. Kurangnya kualitas produk, serta tidak adanya pengemasan produk yang baik

5. Promosi yang masih bersifat tradisional

6. Website belum difungsikan secara maksimal karena kurangnya kemampuan SDM untuk mengelolanya.

\section{Opportunity}

1. Adanya keinginan dari karang taruna, para pembuat jamu, pengrajin kayu dan kuliner makanan tradisional dan perangkat desa untuk maju

2. Adanya peningkatan jumlah wisatawan di Desa Wisata Kaki Langit, Mangunan

3. Adanya kemungkinan kerjasama wisata dengan desa-desa sekitarnya

Thread

1. Kurangnya kemampuan dari karang taruna untuk mengelola desa wisata

2. Adanya persaingan antara desa wisata lain di sekitar Mangunan untuk menarik wisatawan secara kompetitif Kegiatan Pemecahan Masalah Berdasarkan Analisa SWOT tersebut, maka dapat dibentuk strategi sebagai berikut: a. Pelatihan tenaga manajerial kelompok pengrajin. Pada pelatihan ini, pengrajin yang ada akan diberikan suatu proses dan metode pelatihan langsung, untuk mengembangkan sebuah kelompok usaha. Adapupn pelatihan manajerial yang dilakukan meliputi manajemen keuangan dan manajemen produksi secara umum dengan langsung berhadapan dengan permasalahan yang ada. Solusi dan pemecahan permasalahan yang ada, akan dilakukan secara bertahap sesuai dengan kemampuan dan kualitas SDM, hingga target penyampaian materi pelatihan akan dapat tercapai sesuai dengan tahapan dan langkah-langkah yang telah direncanakan.

b. Peningkatan branding produk Pada kegiatan ini, dilakukan branding produk, meliputi kualitas hasil produksi, pengemasan produk, serta penamaan atau merk produk, sehingga dengan meningkatnya branding, nilai jual produk akan meningkat. 


\section{METODE PELAKSANAAN}

\section{Metode}

Tahap awal dilakukan diskusi dengan UMKM di desa wisata Kaki Langit, terutama pembuat jamu tradisional. Untuk memetakan permasalahan dilakukan diskusi dan menghasilkan identifikasi masalah yang berkenaan dengan: 1) Perlunya pemahaman pengemasan produk yang ramah lingkungan, benar dan higienis; 2) Pemahaman pentingnya pembuatan laporan keuangan atau pencataan keuangan untuk mendeteksi tingkat keuntungan usaha UMKM; 3) Untuk pengrajin kayu teridentifikasi bahwa potensi limbah kayu belum dimanfaatkan. Pengrajin masih mengandalkan suplai bahan dari pengorder untuk memproduksi kerajinan.

\section{Pelaksanaan Kegiatan}

Tahap Pelaksanaan. Tahap pelaksanaan pendampingan perlu melakukan identifikasi permasalahan UMKM di desa wisata Kaki Langit yang berkaitan dengan: 1) Pemahaman pengemasan, secara umum UMKM di desa wisata Kaki Langit belum memahami fungsi dan manfaat dari kemasan dan kebersihan kemasan produk yang bisa berdampak pada kepercayaan konsumen dalam mengkonsumsi jamu tradisional. Dalam hal ini perlu digunakan kemasan yang mudah digunakan, ramah lingkungan dan higienis. Solusinya digunakan Standing pouch ramah lingkungan ataupun botol yang baru dengan informasi isi produk yang jelas. 2) Pemahaman pentingnya pembuatan laporan atau pencatatan keuangan. Kondisi keuangan perlu terdeteksi walau sekecil apapun supaya perkembangan keuangan UMKM bisa dipantau pertumbuhanya. Setidaknya pemilik UMKM mengetahui penghitungan harga jual dan laba yang diinginkan; 3) produksi kerajinan kayu perlu memanfaatkan limbah kayu dan diberi merek 'Kaki Langit'.

Tahap Pendampingan. Pelaksanaan pendampingan langsung dengan UMKM di desa wisata Kaki Langit dilakukan pada minggu ke 3 dan 4 bulan Agustus 2020 dan minggu ke 2 dan 3 bulan Juli 2020. Pendampingan menggunakan metode ceramah, diskusi dan contoh-contoh kasus. Selama pendampingan terlihat bahwa pelaku UMKM Kaki Langit memahami pentingya pengemasan produk jamu yang menarik dan higienis untuk menunjang kepercayaan dan peningkatan nilai produk. Desain kreatif yang menekankan struktur material, warna, citra dan elemen-elemen informasi yang digunakan untuk membungkus, melindungi isi, menyimpan dan membedakan dengan produk jamu lain. 
UMKM juga antusias untuk belajar dan memahami pembuatan laporan keuangan atau administrasi keuangan guna untuk mendeteksi perkembangan usaha.

Pada tahap akhir program pendampingan mitra UMKM di desa wisata Kaki Langit masih diajak diskusi untuk pengembangan selanjutnya. Diskusi membahas seputar permasalahan yang muncul setelah pelaksanaan saran dan masukan oleh tim pendamping, terutama contoh-contoh kasus yang berkaitan dengan strategi kemasan produk dan laporan keuangan. Selain metode tersebut di atas guna memantau hasil dan tindak lanjut dari program pendampingan, dibangun sistem komunikasi melalui kontak person untuk keperluan konsultasi dan pemantauan.

\section{HASIL DAN PEMBAHASAN}

Sejak kebijakan pembatasan kontak langsung (less contact) ditetapkan - di awal Maret 2020 - obyek wisata Pasar Semi Kaki Langit tidak ada aktivitas sama sekali. Lebih dari tujuh bulan, komunitas pengelola serta masyarakat sekitar tidak mendapatkan pemasukan sama sekali dari sektor wisata ini. Untuk memenuhi kebutuhan ekonomi, mereka kembali mengelola potensi alam yang dimiliki, seperti hutan dengan kayunya, tegalan dengan tanaman singkongnya dan tanaman-tanaman lain yang bisa dimanfaatkan.

Namun di tengah himpitan keadaan ini, justru tergali potensi-potensi lain yang bisa diintegrasikan dengan aktivitas pariwisata di waktu yang akan datang. Potensi-potensi ini sudah digarap sebelumnya, namun belum optimal karena perhatian pengelola wisata lebih tertuju pada layanannya. Sementara sumberdaya yang lain belum tersentuh. Baru di tengah jeda pandemi ini potensi tersebut diperhatikan.

Beberapa komoditas yang berpotensi diintegrasikan dengan wisata adalah produksi jamu, pengolahan singkong dan pengolahan kayu. Ketiga komoditas tersebut sudah cukup lama digarap. Namun karena penggarapannya masih tradisional dan tidak berorientasi pada peningkatan nilai ekonominya, maka komoditas ini tenggelam dengan sektor wisatanya. Untuk itu, dalam program pengabdian ini dilakukan pelatihan peningkatan nilai ekonomi dari komoditas yang ada:

a. Branding Produk Jamu.

Tanaman obat merupakan salah satu potensi sumberdaya di sekitar Mangunan. Selain menjadi sumber pengobatan tradisional, tanaman obat yang 
cukup banyak bisa dikomodifikasi menjadi produk jamu yang memiliki nilai ekonomi. Sebelumnya karena tidak dianggap memiliki kontribusi yang signifikan dibandingkan dengan aktivitas pariwisata, pengolahan tanaman obat ini kurang serius dilakukan. Namun sejak berhentinya aktivitas wisata, pengolahan produksi jamu ini semakin meningkat. Meski begitu peningkatan produksi ini masih dalam tataran yang sederhana.

Salah satu permasalahan produksi jamu ini adalah pengemasan. Pengemasan jamu sebelumnya dilakukan dengan materi yang sederhana. Tanpa merek dan tanpa petunjuk pemakaian. Padahal sebagai obat, sebuah produk akan lebih bisa dipertanggungjawabkan pemakaiannya apabila terdapat petunjuk pemakaian.

Produk obat (jamu) meski sudah memiliki modal kepercayaan dari konsumennya, namun akan lebih meningkatkan nilai produknya apabila dilengkapi dengan informasi-informasi seputar ingredients, cara pemakaian, identitas jenis produknya, serta kalau perlu ijin dari Badan Pengawas Obat dan Makanan (BPOM).

Untuk langkah pertama, peningkatan nilai produk yang dilakukan dalam pengabdian masyarakat di destinasi wisata Kaki Langit ini adalah memberikan pemahaman melalui ceramah dan sambung rasa mengenai pentingnya pengemasan dan pemberian identitas serta beberapa informasi yang terkait dengan produk. Pengemasan penting dalam konteks komunikasi dengan konsumen. Kemasan memiliki kekuatan primary effect. Konsumen berkomunikasi dengan produk pertama kali melalui kemasan. Tindakan selanjutnya tidak akan dilakukan oleh konsumen manakala konsumen tidak tertarik pada produk. Ketertarikan terbangun pertama kali oleh kemasan. Inilah yang disebut primary effect. Efek dari ketertarikan pertama kali melihat kemasan akan menuntun pada tindakan selanjutnya.

Pemahaman tentang identitas berkisar tentang bagaimana fungsi identitas bagi sebuah produk. Apabila kemasan merupakan daya tarik pertama, identitas merupakan nama (penciri) yang memudahkan konsumen untuk mengingat produk. Konsumen tidak akan mengingat produk apabila mereka tidak memiliki memori tentang namanya. Identitas juga penting untuk membedakan jamu kaki langit dengan jamu yang lainnya. Kekuatan nama terletak pada keunikan dan 
kemudahan bagi konsumen untuk mengingatnya.

Selain kemasan dan identitas produk, masyarakat pembuat jamu juga dijelaskan mengenai isu ramah lingkungan. Pada materi ini terjadi fenomena menarik. Konsep pengemasan yang ramah lingkungan justru datang dari masyarakat produsen sendiri. Artinya kesadaran pelestarian lingkungan sudah tertanam di kalangan komunitas wisata. Sepertinya pembentukan karakter kesadaran lingkungan lebih efektif melalui programprogram yang langsung bersentuhan dengan kepentingan masyarakat. Seperi komunitas pengelola wisata kaki langit ini, mereka terbangun kesadaran lingkungannya karena isu lngkungan sangat sensitif dengan wisata. Pengunjung akan semakin meningkat minatnya apabila destinasi wisata mengedepankan isu lingkungan. Sebaliknya, isu lingkungan juga bisa 'dijual' untuk meningkatkan kunjungan wisata.

Rupanya kesadaran yang terbangun di sektor wisata tersebut menular ke sektor lain. Dalam hal ini pengolahan produk jamu. Ketika disodori ide untuk meningkatkan nilai produk melalui pengemasan, kelompok ini berpesan agar kemasannya terbuat dari materi yang ramah lingkungan. Dengan demikian kemasan yang didisain dalam pengabdian ini adalah standing pouch ecopack yang ramah lingkungan. Standing pouch ecopack yang dipilih adalah untuk produk jamu kemasan 100 gram dan 250 gram.

Sementara untuk disain brand disesuaikan dengan katakter tradisional dari produk. 'Langit' digunakan sebagai brand yang sifatnya simbolik. 'Langit' sudah memiliki kekuatan koherensi dengan 'Kaki Langit'. Oleh karenanya brand 'Langit' akan semakin kuat apabila semua produk yang mensuport produk wisata ini menggunakan brand 'Langit'.
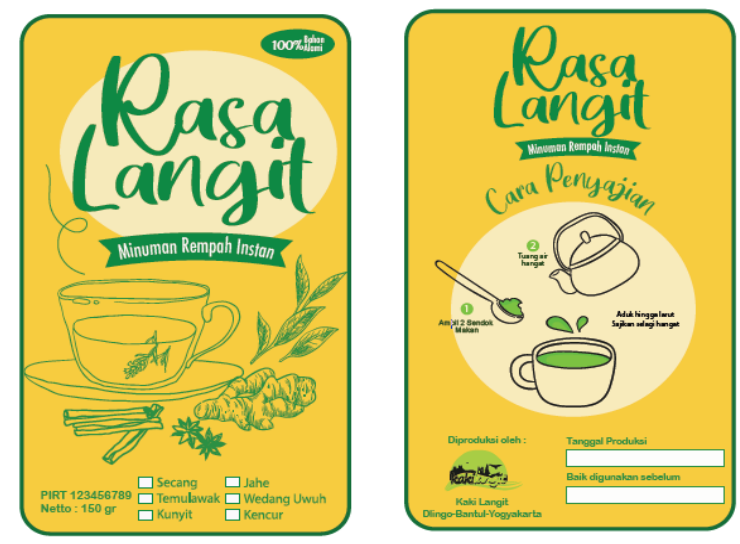

Gambar 1. Logo Produk Jamu

b. Manajemen Keuangan

Masalah umum yang terjadi pada sektor UMKM adalah perihal manajemen keuangan. Demikian juga yang terjadi pada pembuatan jamu di Kaki Langit. Indikator awam yang digunakan untuk mengukur 
kegiatan usaha adalah masih tersedianya modal untuk memproduksi. Sementara untuk permasalahan keuntungan serta perkembangan usaha tidak diperhatikan.

Untuk memberi pemahaman kepada pelaku usaha jamu ini, pertama kali dilakukan dialog mengenai berapa keuntungan yang diperoleh. Ketika ditanyakan keuntungannya dari memproduksi jamu, rata-rata mereka menjawab 'asalkan masih bisa menutup kebutuhan sehari-hari dan masih bisa membeli bahan untuk pembuatan jamu selanjutnya, hal itu dirasa cukup'. Mereka tidak memikirkan upaya untuk pengembangan produk.

Pencatatan keuangan merupakan perihal baru bagi para pembuat jamu. Aktivitas pencatatan keuangan dianggap sebagai 'pekerjaan tambahan' yang tidak perlu bagi mereka. Bisa dipahami bahwa usaha mikro semacam ini lebih banyak berorientasi pada kelanggengan daripada pengembangan. Tidak mudah untuk merubah anggapan bahwa pencatatan tidak diperlukan untuk usaha kecil semacam ini. Namun demikian, materi manajemen keuangan tetap disampaikan dengan lebih berorientasi pada gambaran bahwa produk jamu memiliki potensi untuk dikembangkan lebih besar lagi. Melalui cerita biografi pemilik industri jamu besar yang merintis usahanya dari kecil namun disiplin dalam manajemen keuangannya, produsen jamu kaki langit mulai bisa menerima bahwa kedisiplinan dalam pencatatan penting.

Selanjutnya materi pelatihan pencatatan keuangan masih pada level yang sederhana. Pencatatan cash flow keuangan disesuaikan dengan kondisi pengetahuan para pembuat jamu. Berbeda dengan pengemasan, pencatatan keuangan ini membutuhkan pendampingan yang lebih lama dan perhatian yang terus menerus.

\section{c. Manajemen Produk Kayu}

Sebagai kawasan yang dikelilingi dengan hutan, Kaki Langit memiliki kekayaan kayu yang melimpah. Dalam pemanfaatan kayu menjadi produk olahan, banyak sisa dari hasil olahan kayu yang tidak dimanfaatkan. Krisis Covid-19 ini merangsang masyarakat Kaki Langit yang terdampak untuk memanfaatkan limbah kayu tersebut. Limbah kayu yang semula terbengkelai begitu saja, selanjutnya diolah menjadi beberapa alat penggiling dengan cara pembubutan. Dengan menggunakan alat produksi yang sederhana (mesin sepeda motor), masyarakat Kaki Langit membubut limbah tersebut. Hasilnya ternyata cukup memberikan nilai ekonomi. Masalahnya, 
selama ini mereka hanya menerima orderan dari pedagang secara borongan. Semua bahan kayu dari yang mengorder dan mereka hanya mengerjakan dan memperoleh jasanya saja.

Mengingat materi bahan mentah berlimpah di lingkungan Kaki Langit, maka dalam pengabdian ini pengrajin alat penggiling diarahkan untuk mengolah limbah kayu yang ada dan dijadikan salah satu produk khas Kaki Langit. Dengan diberi brand 'Kaki Langit' produk penggilingan ini juga ikut mengangkat nama Kaki Langit.

\section{PENUTUP}

\section{Simpulan}

Program Pengabdian Masyarakat di Desa Wisata Kaki Langit selama pandemi Covid-19 berfokus pada branding dan pengemasan jamu tradisional sebagai produk baru di desa wisata tersebut. Produk jamu dalam kegiatan $\mathrm{PbM}$ ini dikembangkan sebagai produk pendukung wisata Pasar Semi Kaki Langit sebagai core usaha utama.

Kekuatan sektor UMKM yang berbasis komunitas adalah pada semangat mereka untuk merintis usaha. Semangat ini merupakan modal awal karena akan memudahkan untuk memberikan masukan.
Demikian juga yang terjadi di kalngan 'pengrajin' jamu Kaki Langit. Mereka memiliki semangat untuk berusaha di tengah macetnya kunjungan wisata. Kondisi yang menghimpit justru memunculkan ide untuk mengembangkan sektor lain selain wisata.

Branding 'Jamu Kaki Langit" dikembangkan untuk menguatkan dan melengkapi brand Kaki Langit sebagai tempat wisata. Integrasi dan pengembangan produk sekunder perlu dikembangkan untuk memperkaya produk wisatanya. Pariwisata sebagai core usaha dan produk lain sebagai suportingnya, termasuk jamu 'Kaki Langit'. Mitra merasakan manfaat dari kegiatan $\mathrm{PbM}$ karena Mitra berasa banyak sekali ilmu yang bisa diterapkan guna untuk mengubah cara pengelolaan UMKM yang lebih baik.

\section{Saran}

Masyarakat pengelola wisata Kaki Langit sudah open mind terhadap beberapa isu serta perlunya kreativitas dalam mengembangna potensi objek wisata. Meski demikian, ide-ide mereka masih konvensional. Untuk itu para stakeholder yang melakukan pengabdian masyarakat di Kaki Langit perlu memberikan inovasi yang lebih up date. 


\section{Ucapan Terima Kasih}

Pengabdian kepada masyarakat pengelola wisata Kaki Langit ini sepenuhnya didukung oleh Lembaga Penelitian dan Pengabdian Kepada Masyarakat. Untuk itu kami mengucapkan terima kasih untuk dukungannya. Selanjutnya kami berharap kegiatan ini bisa terus didukung mengingat kerberlanjutan suatu program akan lebih memberikan dampak yang signifikan kepada masyarakat.

\section{REFERENSI}

Dewi, Ike Janita. 2009. Creating \& Sustaining Brand Equity. Yogyakarta: Amara Book.

Estaswara. 2018. Think IMC, Efektivitas Komunikasi untuk Menciptakan
Loyalitas Merek dan Laba Perusahaan. PT Gramedia Pusaka Utama. Jakarta

Sadat, Andi M. 2009. Brand Belief: Strategi Membangun Merek Berbasis Keyakinan. Jakarta: Salemba Empat

Shimp, T.A. 2003. Periklanan Promosi: Aspek Tambahan Komunikasi Pemasaran Terpadu. Sjahrial dan Aniksari, Jakarta: Erlangga.

Jurnal

Kliatchko, J. 2005. Towards a New Definition of Integrated Marketing Communications (IMC). International Journal of Advertising.

Schultz, D.E dan H. Schultz. 2018. Transitioning Marketing Communication into the Twenty-First Century. Journal of Marketing Communications. 